\title{
Effect of Linoleic Acid Supplimentation on Growth of Broiler
}

\author{
Ali Hassan Gaad ${ }^{1}$, Ghulam Shabir Barham ${ }^{2 *}$, Atta Hussain Shah ${ }^{2}$, Gulfam Ali \\ Mughal $^{3}$, Shoaib Ahmed Pirzado ${ }^{4}$, Gul Bahar Khaskheli ${ }^{2}$, Abdul Samad Magsi ${ }^{2}$ \\ and Abdul Aziz Soomro ${ }^{5}$ \\ ${ }^{1}$ Department of Poultry Husbandry, ${ }^{2}$ Department of Animal Products Technology, ${ }^{3}$ Department of Livestock \\ Management and ${ }^{4}$ Department of Animal Nutrition, Faculty of Animal Husbandry and Veterinary Sciences, \\ Sindh Agriculture University Tandojam-Pakistan, ${ }^{5}$ Department of Microbiology, Huazhong Agriculture
} University Wuhan, China.

\begin{abstract}
In order to examine the effect of different levels of linoleic acid supplementation, study was carried out to evaluate the performance of broiler chicken in response to linoleic acid supplement at the Poultry Experiment Station, Department of Poultry Husbandry, Faculty of Animal Husbandry and Veterinary Sciences, Sindh Agriculture University Tandojam. 150 Broiler chicken birds were equally divided in to five groups; $A, B$, $C, D$ and $E$ where the linoleic acid was supplemented in feed at the rates of 0, 0.2, 0.4, 0.6 and $0.8 \%$ in feed, respectively. The feed intake of broiler chicken fed with $0.2 \%$ linolenic acid supplemented ration was significantly $(P<0.05)$ higher than that of 0, 0.4, 0.6 and $0.8 \%$ addition of linolenic acid in ration. Significant $(P<0.05)$ impact of different levels $(0.8,0.6,0.4$ and $0.2 \%)$ of linolenic acid supplementation was noted on weight gain, FCR, final weight, carcass yield and weight of giblets; liver, heart and gizzard of broiler chicken, except dressing percent which is not affected by the supplementation of linoleic acid with basal diet.
\end{abstract}

Keywords: Linoleic acid, Supplementation, Ration, Growth performance and Broiler.

\section{Introduction}

Poultry sector is one of the premeditated and vivacious segments of agriculture industry of Pakistan. It creates employment (direct/indirect) and income for about 1.5 million people. Poultry meat contributes 28.0 percent of the total meat production in the country. The current investment in Poultry Industry is more than Rs. 200.00 billion rupees. Poultry sector has shown a dynamic growth @ 8-10 percent annually which reflects its intrinsic potential. This sector has contributed 1.3 percent in GDP during 2014-15 while its contribution in agriculture and livestock value added stood at 6.3 percent and 11.2 percent, respectively. The poultry value added at current factor cost has increased from Rs. 130.7 billion (2013-14) to 140.5 billion rupees (2014-15) showing an increase of 7.5 percent as compared to previous year. The production of poultry meat is 1074 thousand tons and eggs are 11,307 million numbers [1]. Despite efforts at improved management methods, feed formulation and disease preventive measures adopted in public and private sector [2]. The major objective of poultry production is too efficiently and economically converts relatively unpalatable to unattractive feed stuff in notorious and attractive food for humans. The broiler is a fast growing and high producing bird, which require a concentrated and rapidly digestible diet [3]. Broiler chicken convert feed to live tissue at ratio of a kilogram feed per $\mathrm{kg}$ of live weight gain. For the normal growth and formation of skeleton, birds required balance diet. Broiler converts 2.4 pounds (lbs) of feed in to one 1 pound of chicken and $2.46 \mathrm{lbs}$ of feed into the one pound of egg [4]. Linoleic acid (LA) is a naturally occurring fatty acid found predominantly in beef and dairy products. Linoleic acid is one of the two essential fatty acids (others linolenic acid). Linoleic acid is an omega-6 fatty acid, meaning that it is unsaturated; with a double bond occurring at the sixth carbon atom. The major effect of conjugated linoleic acid (CLA) on animal performance is reducing fat accumulation and promoting muscle growth. CLA repartitioned body fat to lean and improved feed efficiency [5]. CLA supplemented feed induced a rapid and marked decrease in fat accumulation and an increase in protein deposition [6]. It also reduces feed intake and increases feed efficiency. The dietary CLA improved the oxidative stability of cooked chicken meat patties during aerobic storage [7-8].

\section{Material and Methods}

The study was carried out to determine the effect of linoleic acid supplemented ration on the growth performance of the broiler at the Poultry Experiment Station, Department of Poultry Husbandry, Faculty of Animal Husbandry and Veterinary Sciences, Sindh Agriculture University Tandojam.

\subsection{Broiler Chicks}

One hundred fifty (150) day-old Hubbard broiler chicks were purchased were purchased from the local market and brought to the Department of Poultry Husbandry, Sindh Agriculture University Tandojam.

DOI: 10.9790/2380-0908017780 www.iosrjournals.org $77 \mid$ Page




\subsection{Housing And Feeding Of Broiler Chicken}

All the birds initially weighed and randomly divided into five groups A, B, C, D and E having 30 chicks in each group. Uniformity in the housing and management practices was maintained as much as possible for each group. All groups were provided ration having varying levels of linoleic acid. Group A, kept as control, group B, $\mathrm{C}, \mathrm{D}$ and $\mathrm{E}$ were given $0.2 \%, 0.4 \%, 0.6 \%$ and $0.8 \%$ of linoleic acid, respectively. The nutrient composition of feed for broilers during 1 to 42 days of age was formulated according to the standards of National Research Council [9] (Table-1).

Table: 1Feed formulation for broiler chicken

\begin{tabular}{|c|c|c|c|}
\hline $\begin{array}{l}\text { Sr. No. } \\
\text { days) }\end{array}$ & Feed Ingredients & Starter (1-21 days) & Finisher $\quad(22-42$ \\
\hline 1 & Maize, yellow & 36.00 & 45.00 \\
\hline 2 & Soybean meal & 47.00 & 35.00 \\
\hline 3 & Sorghum & 8.00 & 7.00 \\
\hline 4 & Corn Gluten $60 \%$ & 5.00 & 8.00 \\
\hline 5 & DCP & 1.0 & 2.00 \\
\hline 6 & Lime Powder & 1.50 & 2.00 \\
\hline 7 & Mineral Mixture & 0.5 & 0.40 \\
\hline 8 & Multi Vitamin \& feed supplements & 0.5 & 0.25 \\
\hline 9 & Vegetable Oil & 01 & 0.5 \\
\hline & Total & 100.00 & 100.00 \\
\hline \multicolumn{4}{|c|}{ Calculated CP and M. Energy } \\
\hline & $\mathrm{CP}(\%)$ & 27.13 & 24.18 \\
\hline & M.E. Kcal/Kg & 2749 & 2788 \\
\hline
\end{tabular}

\subsection{Variable Analysis}

Following variables has been analyzed through different methods. Feed intake, weight gain and FCR were calculated accordingly.

Feed intake $(\mathrm{g} / \mathrm{bird}=$ feed offered - total fed/Total No. of broilers

Feed conversion ratio [FCR $=$ feed intake $(\mathrm{g}) /$ live weight $(\mathrm{g})]$

After the completion of research trial of 42 days the final live body weight and feed efficiency of broiler of each group was measured. After slaughtering of broiler chicken final body weight, carcass yield, dressing percentage and weight of giblets was also taken.

Dressing percentage $=$ Carcass weight $/$ Live weight $\times 100$

\section{Statistical Analysis}

The data so obtained was tabulated and analyzed according to statistical procedure of Analysis of Variance (ANOVA) and the treatment means were computed using Least Significant Difference (LSD) at 5 level of probability through computerized statistical package i.e. Student Edition of Statistics (SXW), Version 8.1 (Copyright 2005, Analytical Software, USA).

\section{Results}

The influence of different levels of linoleic acid supplementation was observed on the feed intake, body weight and food conversion ratio (FCR) and results are presented in Table-2. The feed intake of broiler chicken fed with $0.2 \%$ linolenic acid supplemented ration $\left(3691 \pm 2.553^{\mathrm{a}}\right)$ was significantly $(\mathrm{P}<0.05)$ higher than that of 0 , $0.4,0.6$ and $0.8 \%$ linolenic acid supplemented ration $\left(3662 \pm 1.054^{\mathrm{b}}, 3603 \pm 1.155^{\mathrm{c}}, 3531 \pm 0.992^{\mathrm{d}}\right.$ and $3493 \pm 1.478^{\mathrm{e}} \mathrm{g} / \mathrm{bird}$, respectively). However, significant $(\mathrm{P}<0.05)$ influence of linolenic acid supplementation was noted on body weight and FCR of broiler chicken fed with $0.8 \%\left(1893 \pm 1.453^{\mathrm{a}} \mathrm{g} / \mathrm{bird}\right.$ and $\left.2.11 \pm 0.013^{\mathrm{a}}\right)$, $0.6 \%\left(1845 \pm 1.498^{\mathrm{b}} \mathrm{g} / \mathrm{bird}\right.$ and $\left.2.02 \pm 0.083^{\mathrm{b}}\right), 0.4 \%\left(1837 \pm 1.358^{\mathrm{c}} \mathrm{g} / \mathrm{bird}\right.$ and $\left.1.95 \pm 0.054^{\mathrm{c}}\right)$ and $0.2 \%$ $\left(1824 \pm 1.579^{\mathrm{d}} \mathrm{g} / \mathrm{bird}\right.$ and $\left.1.91 \pm 7.63^{\mathrm{d}}\right)$ linolenic acid supplemented ration compared to that of non supplemented birds $\left(1732 \pm 1.945^{\mathrm{e}} \mathrm{g} /\right.$ bird and $\left.1.89 \pm 0.119^{\mathrm{d}}\right)$.

Table: 2 Effect of linoleic acid supplemented ration on feed intake, body weight and FCR of broiler chicken

\begin{tabular}{|l|l|l|l|l|l|l|}
\hline \multirow{2}{*}{ Variables } & \multicolumn{5}{|l|}{ Broiler chicken supplemented with linoleic acid supplemented ration } \\
\cline { 2 - 7 } & $\mathbf{A ~ ( 0 )}$ & $\mathbf{B}(\mathbf{0 . 2 \%})$ & $\mathbf{C ~ ( 0 . 4 \% )}$ & $\mathbf{D}(\mathbf{0 . 6 \%})$ & $\mathbf{E} \mathbf{( 0 . 8 \% )}$ & LSD \pm SE (0.05) \\
\hline Feed intake (g/bird) & $3662 \pm 1.054^{\mathrm{b}}$ & $3691 \pm 2.553^{\mathrm{a}}$ & $3603 \pm 1.155^{\mathrm{c}}$ & $3531 \pm 0.992^{\mathrm{d}}$ & $3493 \pm 1.478^{\mathrm{e}}$ & $4.5362 \pm 2.2025$ \\
\hline Body weight (g/bird) & $1732 \pm 1.945^{\mathrm{e}}$ & $1824 \pm 1.579^{\mathrm{d}}$ & $1837 \pm 1.358^{\mathrm{c}}$ & $1845 \pm 1.498^{\mathrm{b}}$ & $1893 \pm 1.453^{\mathrm{a}}$ & $4.6012 \pm 2.2341$ \\
\hline FCR & $1.89 \pm 0.119^{\mathrm{d}}$ & $1.91 \pm 7.63^{\mathrm{d}}$ & $1.95 \pm 0.054^{\mathrm{c}}$ & $2.02 \pm 0.083^{\mathrm{b}}$ & $2.11 \pm 0.013^{\mathrm{a}}$ & $0.0261 \pm 0.0128$ \\
\hline
\end{tabular}

*Means with different letters in same row varied significantly from one another. FCR=Feed conversion ratio. 
Remarkable $(\mathrm{P}<0.05)$ increase was noticed in final body weight and carcass yield of broiler chicken fed with $0.8 \%\left(1989 \pm 0.764^{\mathrm{a}}\right.$ and $\left.1163 \pm 0.946^{\mathrm{a}} \mathrm{g} / \mathrm{bird}\right), \quad 0.4 \% \quad\left(1904 \pm 1.183^{\mathrm{b}}\right.$ and $\left.1132 \pm 0.992^{\mathrm{b}} \mathrm{g} / \mathrm{bird}\right), 0.2 \%$ $\left(1891 \pm 1.202^{\mathrm{c}}\right.$ and $\left.1128 \pm 0.792^{\mathrm{c}} \mathrm{g} / \mathrm{bird}\right)$, except broiler fed with $0.6 \%\left(1863 \pm 0.946^{\mathrm{d}}\right.$ and $\left.1085 \pm 1.302^{\mathrm{e}} \mathrm{g} / \mathrm{bird}\right)$ and $0 \%\left(1823 \pm 1.478^{\mathrm{e}}\right.$ and $\left.1109 \pm 0.764^{\mathrm{d}} \mathrm{g} / \mathrm{bird}\right)$ linolenic acid supplemented ration (Table-3). Whereas, the dressing percent of broiler chicken fed with $0 \%$ lenoleic acid supplemented ration found comparatively $(\mathrm{P}<0.05)$ higher $\left(61.0 \pm 0.045^{\mathrm{a}}\right)$, followed by birds fed with $0.2,0.4,0.6$ and $0.8 \%$ lenoleic acid supplementation $\left(60.0 \pm 0.034^{\mathrm{b}}\right.$, $59.44 \pm 0.019^{\mathrm{c}}, 58.36 \pm 0.021^{\mathrm{d}}$ and $58.34 \pm 0.816^{\mathrm{d}}$, respectively).

Table: 3 Impact of linoleic acid supplemented ration on final body weight, carcass yield and dressing percent of broiler chicken

\begin{tabular}{|l|l|l|l|l|l|l|}
\hline \multirow{2}{*}{ Variables } & \multicolumn{5}{|l|}{ Broiler chicken supplemented with linoleic acid supplemented ration } \\
\cline { 2 - 7 } & $\mathbf{A ~ ( 0 )}$ & $\mathbf{B}(\mathbf{0 . 2 \%})$ & $\mathbf{C}(\mathbf{0 . 4 \%})$ & $\mathbf{D}(\mathbf{0 . 6 \%})$ & $\mathbf{E} \mathbf{( 0 . 8 \% )}$ & LSD \pm SE $\mathbf{( 0 . 0 5 )}$ \\
\hline Final weight (g/bird) & $1823 \pm 1.478^{\mathrm{e}}$ & $1891 \pm 1.202^{\mathrm{c}}$ & $1904 \pm 1.183^{\mathrm{b}}$ & $1863 \pm 0.946^{\mathrm{d}}$ & $1989 \pm 0.764^{\mathrm{a}}$ & $3.3223 \pm 1.6131$ \\
\hline Carcass yield (g/bird) & $1109 \pm 0.764^{\mathrm{d}}$ & $1128 \pm 0.792^{\mathrm{c}}$ & $1132 \pm 0.992^{\mathrm{b}}$ & $1085 \pm 1.302^{\mathrm{e}}$ & $1163 \pm 0.946^{\mathrm{a}}$ & $2.8488 \pm 1.3832$ \\
\hline Dressing percent (\%) & $61.0 \pm 0.045^{\mathrm{a}}$ & $60.0 \pm 0.034^{\mathrm{b}}$ & $59.44 \pm 0.019^{\mathrm{c}}$ & $58.36 \pm 0.021^{\mathrm{d}}$ & $58.34 \pm 0.816^{\mathrm{d}}$ & $0.0835 \pm 0.0405$ \\
\hline
\end{tabular}

*Means with different letters in same row varied significantly from one another.

The weight of giblets; liver, heart and gizzard (Table-4) was observed significantly $(\mathrm{P}<0.05)$ higher in broiler chicken fed with $0.8 \%\left(53.78 \pm 0.024^{\mathrm{a}}, 15.95 \pm 0.011^{\mathrm{a}}\right.$ and $32.87 \pm 0.014^{\mathrm{a}} \mathrm{g} /$ bird, respectively), followed by $0.6 \%\left(52.43 \pm 0.012^{\mathrm{b}}, 15.72 \pm 0.715^{\mathrm{b}}\right.$ and $32.20 \pm 0.095^{\mathrm{b}} \mathrm{g} / \mathrm{bird}$, respectively), $0.4 \%\left(49.00 \pm 0.092^{\mathrm{c}}, 14.88 \pm 0.086^{\mathrm{c}}\right.$ and $31.23 \pm 0.087^{\mathrm{c}} \mathrm{g} / \mathrm{bird}$, respectively) and $0.2 \%\left(48.51 \pm 0.015^{\mathrm{d}}, 14.48 \pm 0.088^{\mathrm{d}}\right.$ and $29.66 \pm 0.014^{\mathrm{d}} \mathrm{g} / \mathrm{bird}$, respectively) compared to that of broiler fed with $0 \%$ linolenic acid supplemented ration $\left(46.00 \pm 0.014^{\mathrm{e}}\right.$, $14.22 \pm 0.013^{\mathrm{e}} 27.50 \pm 0.095^{\mathrm{e}} \mathrm{g} / \mathrm{bird}$, respectively).

Table: 4 Influence of linoleic acid supplemented ration on giblets; liver, heart and gizzard of broiler chicken

\begin{tabular}{|c|c|c|c|c|c|c|}
\hline \multirow[b]{2}{*}{ Giblets } & \multicolumn{6}{|c|}{ Broiler chicken supplemented with linoleic acid supplemented ration } \\
\hline & $\mathbf{A}(\mathbf{0})$ & В (0.2\%) & $\mathrm{C}(0.4 \%)$ & $\mathrm{D}(\mathbf{0 . 6 \% )}$ & E $(0.8 \%)$ & $\mathrm{LSD} \pm \mathrm{SE}(\mathbf{0 . 0 5})$ \\
\hline Liver $(\mathrm{g} / \mathrm{bird})$ & $46.00 \pm 0.014^{\mathrm{e}}$ & $48.51 \pm 0.015^{\mathrm{d}}$ & $49.00 \pm 0.092^{\mathrm{c}}$ & $52.43 \pm 0.012^{\mathrm{b}}$ & $53.78 \pm 0.024^{\mathrm{a}}$ & $0.0452 \pm 0.0219$ \\
\hline Heart (g/bird) & $14.22 \pm 0.013^{\mathrm{e}}$ & $14.48 \pm 0.088^{\mathrm{d}}$ & $14.88 \pm 0.086^{\mathrm{c}}$ & $15.72 \pm 0.715^{\mathrm{b}}$ & $15.95 \pm 0.011^{\mathrm{a}}$ & $0.0284 \pm 0.0138$ \\
\hline Gizzard (g/bird) & $27.50 \pm 0.095^{\mathrm{e}}$ & $29.66 \pm 0.014^{\mathrm{d}}$ & $31.23 \pm 0.087^{\mathrm{c}}$ & $32.20 \pm 0.095^{\mathrm{b}}$ & $32.87 \pm 0.014^{\mathrm{a}}$ & $0.0331 \pm 0.0161$ \\
\hline
\end{tabular}

*Means with different letters in same row varied significantly from one another.

\section{Discussion}

In the present study the feed intake of broiler chicken fed with $0.2 \%$ linolenic acid supplemented ration was significantly $(\mathrm{P}<0.05)$ higher than that of $0,0.4,0.6$ and $0.8 \%$ linolenic acid supplemented ration. These results are well accordance to Szymezyk [10], who reported that daily feed intake of the broilers fed with high level of linoleic acid based diets was lower than those who fed with non supplemented and low level of lenoleic acid. However, other Researchers are also agreed with the results of present study who reported that feed with supplementation gave greater feed intake than did mash forms in the broiler chickens [11, 12 and13]. Significant $(\mathrm{P}<0.05)$ influence of linolenic acid supplementation was noted on body weight and FCR of broiler chicken fed with $0.8,0.6,0.4$ and $0.2 \%$ linolenic acid supplemented ration compared to that of non supplemented birds during the present investigation. These findings are in the line of results reported by Jahan et al. [14] who indicated that the highest body weight and FCR throughout all of the weeks was observed in crumble group, whereas the lowest body weight in different weeks were observed mash group of broiler. Similarly Shoaib et al. [15] reported that values of feed conversion ratio (FCR) were comparatively improved in broilers fed with supplemented ration. In the current study remarkable $(\mathrm{P}<0.05)$ increase was noticed in final body weight and carcass yield of broiler chicken fed with lenoleic acid supplemented ration (0.8, 0.60 .4 and $0.2 \%$ ), except dressing percent which found comparatively higher in birds which were fed with non supplemented diet. These results are in line with findings of Kim and Chung [11] and Shoaib et al. [15] they found significant increase in body weight and carcass yield of broiler chicken fed with supplemented ration and slow body growth in birds fed with non supplemented diet. In accordance with current study Wittman et al. [16] reported that diet supplemented with conjugated linoleic acid had non-significant effect on dressing percent of broiler chicken. Park et al. and Delany et al. [6 and 17] stated that due to the supplementation of lenoleic acid the growth rate of broilers is increased due to the increase in the protein content with in their body. In the present study the weight of giblets; liver, heart and gizzard was significantly $(\mathrm{P}<0.05)$ increased in broiler chicken fed with 0.8, 0.6, 0.4 and $0.2 \%$ than that of fed with basal (0\%) diet. These results are in agreement with Du and Ahn [18], they reported that giblets; liver, heart and gizzard weight of broilers were significantly increased with the supplementation of conjugated linoleic acid. 


\section{Conclusions}

On the basis of present findings it was concluded that the broiler chicken fed with ration supplemented with different levels of lenoleic acid $(0.2,0.4,0.6$ and $0.8 \%)$ received highest feed conversion ratio with lowest feed intake, maximum body weight, carcass yield and edible giblets weight compared to that of birds fed with basal diet/non-supplemented ration.

\section{References}

[1]. Farooque, O. Agriculture. Pakistan Economic Survey 2014-15. Economic Advisers' Wing Finance Division, Government of Pakistan, Islamabad.

[2]. Chehraghi, M. A. Zakeri and M. Taghinejad-Roudbaneh. Effects of different feed forms on performance in broiler chickens. European Journal of Experimental Biology, 23(4): 2013, 66-70.

[3]. Ko, Y.H., H.Y. Yang and I.S. Jang. Effect of conjugated linoleic acid on intestinal and hepatic antioxidant enzyme activity and lipid per oxidation in broiler chickens. Asian-Australasian Journal of Animal Sciences. 17(8): 2004, 1162-1167.

[4]. Aletor, V. A., K. Eder, K. Becker, B.R. Paulicks, F.X. Roth and D.A. Roth-Maier. The effects of conjugated linoleic acids or/and 945;-glycosidase inhibitor on tissue lipid concentrations and fatty acid composition of broiler chicks fed a low-protein diet. Poultry Science. 82(5): 2003, 796-804.

[5]. Park, Y., K.J. Albright, W. Liu, J.M. Storkson, M.E. Cook, and M.W. Pariza. Effect of conjugated linoleic acid on body composition in mice. Lipids. (32): 1997, 853-858.

[6]. Park, Y., K.J. Albright, J. M. Storkson, W. Liu, and M.W. Pariza. Evidence that the trans-10, cis-12 isomer of conjugated linoleic acid induces body composition changes in mice. Lipids. (34): 1999, 235-241.

[7]. Dugan, M. E. R., J.L. Aalhus, L.E. Jeremiah, J.K.G. Kramer, and A.L. Schaefer. The effects of feeding conjugated linoleic acid on subsequent pork quality. Canadian Journal of Animal Science. (79): 199945-51.

[8]. Du, M., D.U. Ahn, K.C. Nam, and J.L. Sell. Volatile profiles and lipid oxidation of irradiated cooked chicken meat from laying hens fed with diets containing conjugated linoleic acid. Poultry Science. (80): 2001, 1749-1756.

[9]. National Research Council (NRC). Nutrient requirements of poultry. $9^{\text {th }}$ edition. National Academy Press, Washington DC, 1994.

[10]. Szymczyk, B., P.M. Pisulewski, W. Szczurek and P. Hanczakowski. Effects of conjugated linoleic acid on growth performance, feed conversion efficiency and subsequent carcass quality in broiler chickens. British Journal of Nutrition. 85(4): 2001, 465-473.

[11]. Kim, H.H. and Y.H. Chung. Effects of dietary feed form regimens on broiler chicken performance. Journal of Agriculture Science and Livestock. 35, 1996, 554-558.

[12]. Preston, C. M., R.J. McCracken and A. McAllister. Effect of diet form and enzyme supplementation on growth, efficiency and energy utilization of wheat based diets for broilers. British Poultry Science. 41, 2000, 324-331.

[13]. Munt, R.H.C., J.G. Dingle and M.G. Sumpa. Growth, carcass composition and profitability of meat chickens given pellets, mash or free choice diet. British Poultry Science. 36, 1995, 277-284.

[14]. Jahan, M. S., M. Asaduzzaman and A. K. Sarkar. Performance of broiler fed on mash, pellet and crumble. International Journal of Poultry Science. 5 (3), 2006, 265-270.

[15]. Pirzado, S. A., Pirzado, A.S. Mangsi, G.S. Barham, G.M Mari, Z. Pirzado and Q. Kalwa. Effect of mash and crumbled feed forms on the performance of broiler chickens. Journal of Agriculture and Veterinary Science. 8(12): 2015, 27-30

[16]. Wittmann, M., S. Najati and M. Kreuzer. Minimizing the effects of dietary animal fat on product quality in broiler chicks and Muscovy ducks by taking into account the ratio of linoleic acid to energy. Fat/Lipid. 98(3): 1996, 109-114.

[17]. DeLany, J. P., F. Blohm, A. A. Truett, J. A. Scimeca, and D. B. West. 1999. Conjugated linoleic acid rapidly reduces body fat content in mice without affecting energy intake. American Journal of Physiology. (276): 1999, 1172-1179.

[18]. Du, M. and D.U. Ahn. Dietary CLA affects lipid metabolism in broiler chicks. Lipids. 38(5): 2003, 505-511 